\title{
Use of Lithium Diisopropylamide in Flow: Operability and Safety Challenges Encountered on Multigram Scale
}

\author{
Marta Alonsof; Maria Cruz Garciał; Christopher McKayt; Lee R. Thorp §; \\ Michael Webb†; Lee J. Edwards*† \\ † Chemical Development, GlaxoSmithKline, Gunnels Wood Road, Stevenage, SG1 2NY, UK \\ $¥$ Medicinal Chemistry, GlaxoSmithKline, Severo Ochoa, 2 P.T.M. Tres Cantos, Madrid 28760, Spain \\ \$Medicinal Chemistry, GlaxoSmithKline, Gunnels Wood Road, Stevenage, SG1 2NY, UK
}

\section{Supporting information}

Contents

General information

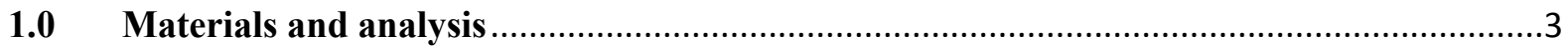

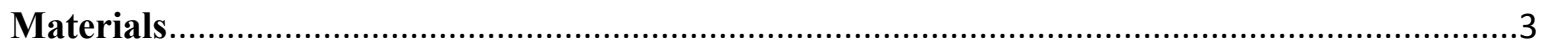

High performance liquid chromatography (HPLC) ….....................................................

Low resolution liquid chromatography mass spectrometry (LCMS) method 1.......................4

Low resolution liquid chromatography mass spectrometry (LCMS) method 2.......................5

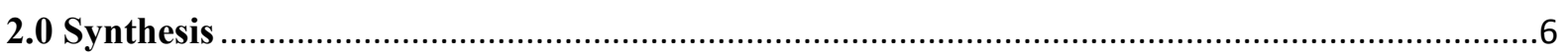

Synthesis of 5-bromo-2-(2-methylprop-1-en-1-yl)pyridine 4 …..........................................

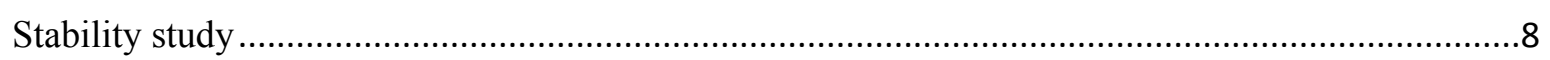

Synthesis of 1-(5-bromopyridin-2-yl)-2-methylpropan-2-ol 1 …...........................................

Synthesis of 1-(5-bromopyridin-2-yl)-2-methylpropan-2-ol monohydrochloride 1 ....................14

Synthesis of 1-(5-bromopyridin-2-yl)-2-methylpropan-2-ol 1 final processing run ....................17

Photos of 2M LDA in THF/heptane/ethylbenzene after cooling to $<-60^{\circ} \mathrm{C}$....................................22

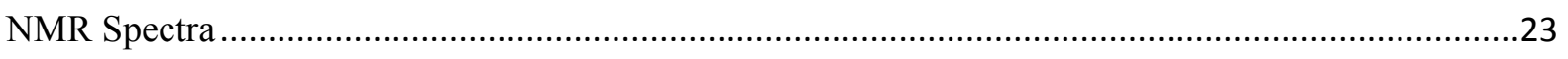

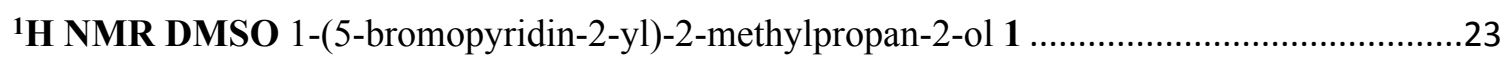

${ }^{1}$ H NMR DMSO 1-(5-bromopyridin-2-yl)-2-methylpropan-2-ol monohydrochloride 1 ............23

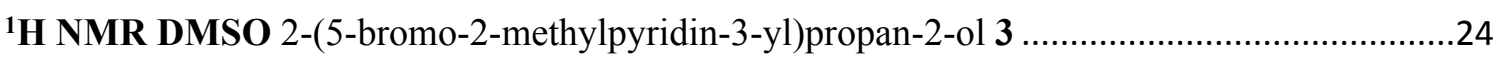

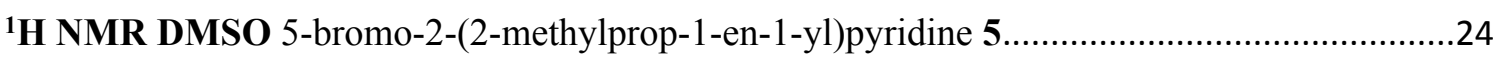

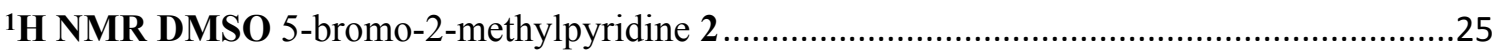




\section{General information}

\subsection{Materials and analysis}

\section{Materials}

Reagents were obtained commercially, from Combi-Blocks and Sigma-Aldrich, and used as received. Solvents were used wet unless otherwise stated, and reactions were not performed under an inert atmosphere unless otherwise stated.

Wheaton vial details, Item\# 224882 \& W242710

\section{High performance liquid chromatography (HPLC)}

These data were recorded on an Agilent HPLC system, equipped with a Waters X-select CSH $\mathrm{C} 18$ (30 mm length $\times 2.0 \mathrm{~mm}$ internal diameter, $2.5 \mu \mathrm{m}$ packing particle size) at $40{ }^{\circ} \mathrm{C}$.

The solvents employed were:

$\mathrm{A}=$ Water $+0.05 \% \mathrm{TFA}$

$\mathrm{B}=$ Acetonitrile $+0.05 \% \mathrm{TFA}$

The gradient employed was as follows:

\begin{tabular}{cccc}
\hline Time (min) & Flow rate (mL/min) & $\%$ A / \% & $\%$ B / \% \\
\hline 0 & 1.0 & 97 & 3 \\
3.7 & 1.0 & 5 & 95 \\
4.00 & 1.0 & 5 & 95 \\
4.01 & 1.0 & 97 & 3 \\
5.5 & 1.0 & 97 & 3 \\
\hline
\end{tabular}

The UV response was monitored at a wavelength of $220 \mathrm{~nm}$. 
Method 1 used throughout unless otherwise stated.

\section{Low resolution liquid chromatography mass spectrometry (LCMS) method 1.}

These data were recorded using a Waters Acquity UPLC, equipped with a CSH C18 column $\left(50 \mathrm{~mm} \times 2.1 \mathrm{~mm}\right.$ internal diameter, $1.7 \mu \mathrm{m}$ packing diameter) at $40^{\circ} \mathrm{C}$.

The solvents employed were:

$\mathrm{A}=10 \mathrm{mM}$ ammonium bicarbonate in water, adjusted to $\mathrm{pH} 10$ with ammonia solution.

$\mathrm{B}=$ acetonitrile

The gradient employed was as follows:

\begin{tabular}{cccc}
\hline Time / min & Flow rate / $\mathbf{m L ~ m i n}^{-\mathbf{1}}$ & $\mathbf{\%} \mathbf{A} / \%$ & $\% \mathbf{~ B ~ / ~ \% ~}$ \\
\hline 0 & 1 & 97 & 3 \\
0.05 & 1 & 97 & 3 \\
1.5 & 1 & 5 & 95 \\
1.9 & 1 & 5 & 95 \\
2.0 & 1 & 97 & 3 \\
\hline
\end{tabular}

The UV detection was an averaged signal from wavelength of $210 \mathrm{~nm}$ to $350 \mathrm{~nm}$ and mass spectra were recorded on a Waters ZQ mass spectrometer using alternate-scan positive and negative electrospray ionization (ES). 


\section{Low resolution liquid chromatography mass spectrometry (LCMS) method 2.}

These data were recorded using a Waters Acquity UPLC, equipped with a Acquity UPLC BEH C18 $(50 \mathrm{~mm} \times 3.0 \mathrm{~mm}$ internal diameter, $1.7 \mu \mathrm{m}$ packing diameter $)$ at $50{ }^{\circ} \mathrm{C}$.

The solvents employed were:

$\mathrm{A}=$ water $0.1 \%$ formic acid

$\mathrm{B}=$ acetonitrile $0.1 \%$ formic acid

The gradient employed was as follows:

\begin{tabular}{cccc}
\hline Time / min & Flow rate / $\mathbf{m L ~ m i n}^{-1}$ & $\mathbf{\%} \mathbf{A} / \%$ & $\% \mathbf{~ B ~ / ~ \% ~}$ \\
\hline 0 & 0.8 & 95 & 5 \\
1.4 & 0.8 & 0 & 100 \\
1.9 & 0.8 & 0 & 100 \\
& & & \\
2.0 & 0.8 & 95 & 5 \\
\hline
\end{tabular}

The UV detection was an averaged signal from wavelength of $210 \mathrm{~nm}$ to $350 \mathrm{~nm}$ and mass spectra were recorded on a Waters ZQ mass spectrometer using alternate-scan positive and negative electrospray ionization (ES). 


\subsection{Synthesis}

Synthesis of 5-bromo-2-(2-methylprop-1-en-1-yl)pyridine 5<smiles>CC(C)[P+](c1ccccc1)(c1ccccc1)c1ccccc1</smiles>

$1^{-}$<smiles>O=Cc1ccc(Br)cn1</smiles><smiles>CO[N+](=O)[O-]</smiles><smiles>CC(C)=Cc1ccc(Br)cn1</smiles>

A mixture of 5-bromopicolinaldehyde (100 mg, $0.538 \mathrm{mmol})$, isopropyltriphenylphosphonium iodide $(256 \mathrm{mg}, 0.591 \mathrm{mmol})$ and sodium hydroxide $(0.806$ $\mathrm{mL}, 1.613 \mathrm{mmol})$ in Dichloromethane (DCM) (4 mL) were stirred at room temperature for $18 \mathrm{hrs}$. Additional sodium hydroxide $(0.806 \mathrm{~mL}, 1.613 \mathrm{mmol})$ was added and stirred at room temperature for $4 \mathrm{hr}$, after which time sodium hydroxide $(0.806 \mathrm{~mL}, 1.613 \mathrm{mmol})$ was added and stirred at room temperature for a further $18 \mathrm{hrs}$.

DCM (4 mL) and water $(4 \mathrm{~mL})$ were added the layers were separated. Organic layer was dried over $\mathrm{Na}_{2} \mathrm{SO}_{4}$, filtered and concentrated in vacuo, . The crude was purified by normal phase column chromatography (gradient 0 to $5 \%$ Cyclohexane/EtOAc) to give $70 \mathrm{mg}$ of title compound 5-bromo-2-(2-methylprop-1-en-1-yl)pyridine 4. ${ }^{1} \mathrm{H}$ NMR (400 MHz, DMSO-d 6 ) $\delta$ $1.91(\mathrm{~d}, J=1.00 \mathrm{~Hz}, 3 \mathrm{H}), 2.08(\mathrm{~d}, J=1.01 \mathrm{~Hz}, 3 \mathrm{H}), 6.27-6.28(\mathrm{~m}, 1 \mathrm{H}), 7.22(\mathrm{~d}, J=8.34 \mathrm{~Hz}$, 1H), $7.95(\mathrm{dd}, J=8.34,2.53 \mathrm{~Hz}, 1 \mathrm{H}), 8.62(\mathrm{~d}, J=2.53 \mathrm{~Hz}, 1 \mathrm{H}) ; . \mathrm{LC} / \mathrm{MS}, 1.41 \mathrm{~min}(\mathrm{ES}+) \mathrm{m} / \mathrm{z}$ (relative intensity) 212/214 ([M+H]+.,95) method 2 .

NOTE: 5-bromo-2-(2-methylprop-1-en-1-yl)pyridine $\mathbf{5}$ is volatile, evaporation process was carried out without heating. 


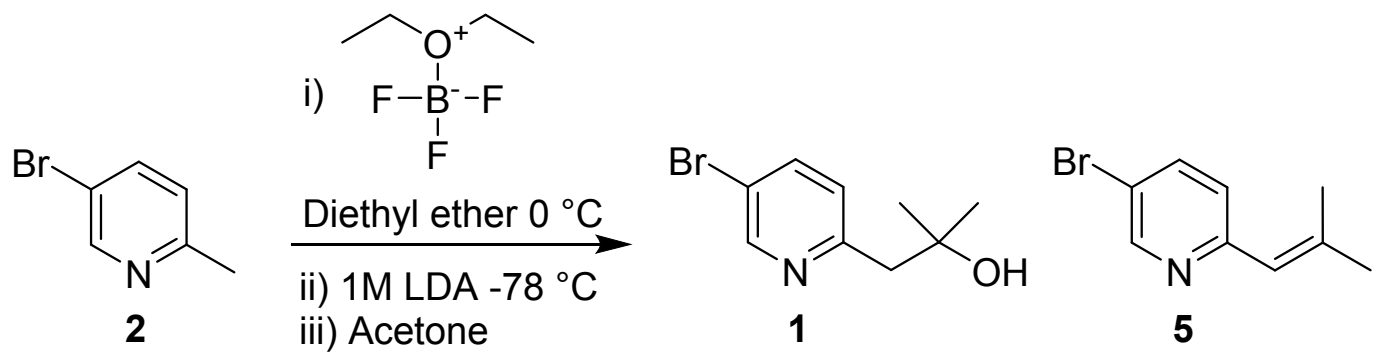

To a solution of 5-bromo-2-methylpyridine $2(200 \mathrm{mg}, 1.163 \mathrm{mmol})$ in diethyl ether $(7 \mathrm{~mL})$ under Argon at $0{ }^{\circ} \mathrm{C}$ was added boron trifluoride etherate $(0.158 \mathrm{~mL}, 1.279 \mathrm{mmol})$. The resulting suspension was stirred at $0^{\circ} \mathrm{C}$ for 10 minutes. It was cooled to $-78^{\circ} \mathrm{C}$ and lithium diisopropylamide, $1.0 \mathrm{M}$ in THF $(1.628 \mathrm{~mL}, 1.628 \mathrm{mmol})$ was dropwise added to the reaction mixture. After $20 \mathrm{~min}$, Acetone $(0.256 \mathrm{~mL}, 3.49 \mathrm{mmol})$ was added, and the solution was brought to room temperature.

After $1 \mathrm{hr}$, LC-MS showed a mixture of 2, 1 and major peak corresponding with dehydration product (5-bromo-2-(2-methylprop-1-en-1-yl)pyridine) 5.

The reaction mixture was quenched with water and it was extracted with diethyl ether. The organic layer was dried over $\mathrm{Na}_{2} \mathrm{SO}_{4}$, filtered and concentrated in vacuo to give the crude product, during concentration step material lost. The crude product was purified by normal phase column chromatography (cyclohexane/ ethyl acetate gradient $0-50 \%$ ). To give the title compound 5-bromo-2-(2-methylprop-1-en-1-yl)pyridine $58 \mathrm{mg}$ and recovered 5-bromo-2methylpyridine 286 mg. No 1-(5-bromopyridin-2-yl)-2-methylpropan-2-ol 1 isolated.

Note fractions concentrated in vacuo without heat.

5-Bromo-2-(2-methylprop-1-en-1-yl)pyridine $58 \mathrm{mg} ;{ }^{1} \mathrm{H}$ NMR (400 MHz, DMSO-d $\left.{ }_{6}\right) \delta$ $1.91(\mathrm{~d}, J=1.00 \mathrm{~Hz}, 3 \mathrm{H}), 2.08(\mathrm{~d}, J=1.01 \mathrm{~Hz}, 3 \mathrm{H}), 6.27-6.28(\mathrm{~m}, 1 \mathrm{H}), 7.22(\mathrm{~d}, J=8.34 \mathrm{~Hz}$, $1 \mathrm{H}), 7.95$ (dd, $J=8.34,2.53 \mathrm{~Hz}, 1 \mathrm{H}), 8.62(\mathrm{~d}, J=2.53 \mathrm{~Hz}, 1 \mathrm{H})$

5-Bromo-2-methylpyridine $286 \mathrm{mg} ;{ }^{1} \mathrm{H}$ NMR (400 MHz, DMSO-d 6 ) $\delta 2.44$ (s, 3H), 7.26 (d, $J=8.37 \mathrm{~Hz}, 1 \mathrm{H}), 7.91$ (dd, $J=8.37,2.46 \mathrm{~Hz}, 1 \mathrm{H}), 8.55$ (d, $J=2.46 \mathrm{~Hz}, 1 \mathrm{H})$ 
Stability study

Synthesis of 1-(5-bromopyridin-2-yl)-2-methylpropan-2-ol 1

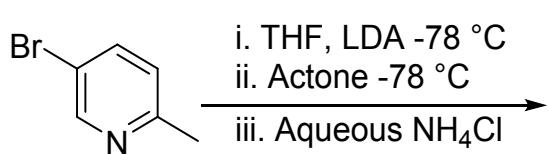

2<smiles>CC(C)(O)Cc1ccc(Br)cn1</smiles>

1<smiles>Cc1ncc(Br)cc1C(C)(C)O</smiles>

3<smiles>CC(=O)CC(C)(C)O</smiles>

4<smiles>CC(C)=Cc1ccc(Br)cn1</smiles>

5

Dry acetone: Calcium sulfate $(80 \mathrm{~g}, 588 \mathrm{mmol})$ was added to acetone $(1800 \mathrm{~mL})$, mixture was allowed to stand at room temperature overnight.

5-bromo-2-methylpyridine 2 (50 g, $291 \mathrm{mmol})$ was dissolved in dry Tetrahydrofuran (THF, $1000 \mathrm{ml})$

Reactor system cooled to $-70{ }^{\circ} \mathrm{C}$, see Figure 15 in manuscript

Reactor flushed under at the flowing flow rates for $6 \mathrm{~min}$.

2M LDA in THF $1.3 \mathrm{ml} / \mathrm{min}$

Feedline $5.98 \mathrm{~g} / \mathrm{min}$ (THF)

Dry acetone $1.22 \mathrm{ml} / \mathrm{min}$

After initial 6 min changed to

2M LDA in THF $1.3 \mathrm{ml} / \mathrm{min}$

Feedline $5.98 \mathrm{~g} / \mathrm{min}$ 5-bromo-2-methylpyridine 2 in THF

Dry acetone $1.22 \mathrm{ml} / \mathrm{min}$

After a further 6 min, blockage on LDA line, LDA frozen in T-mixer

2M LDA replaced with 1M LDA in THF/Hexanes (1:7)

$1 \mathrm{M}$ LDA $1.3 \mathrm{ml} / \mathrm{min}$

Feedline $5.98 \mathrm{~g} / \mathrm{min}$ 5-bromo-2-methylpyridine 2 in THF

Dry acetone $1.22 \mathrm{ml} / \mathrm{min}$ 
Sampled every 3 min during start up, see Figure S1

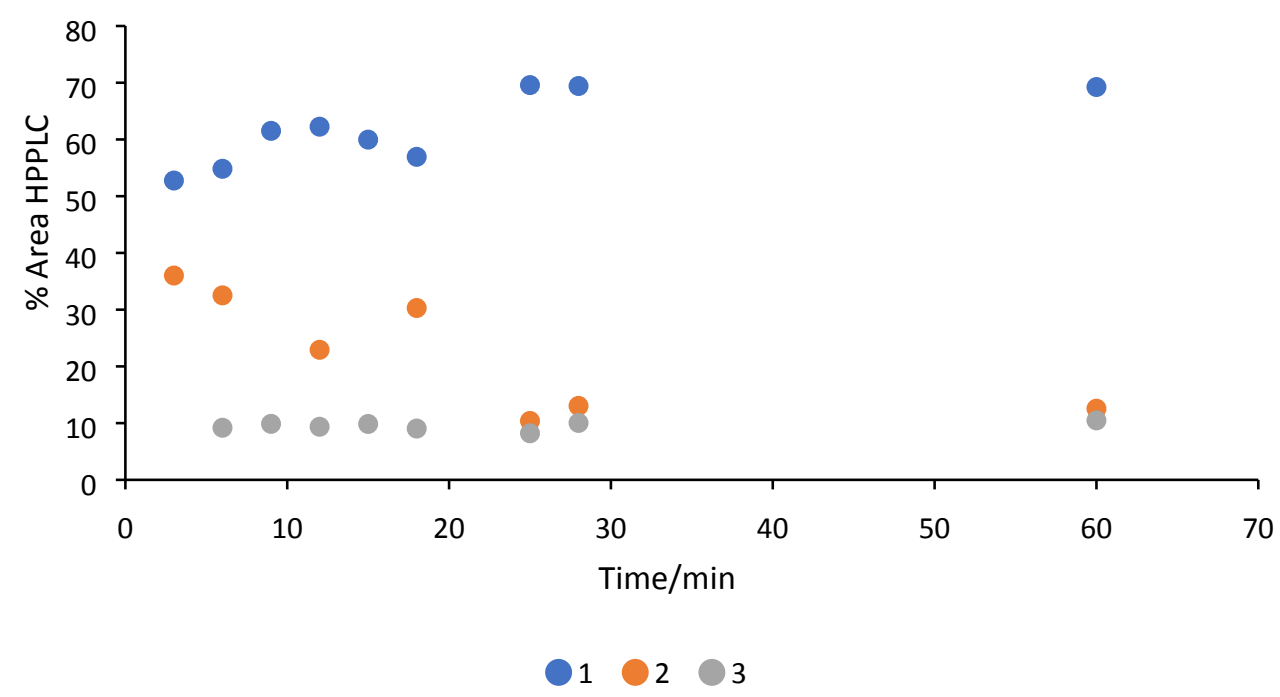

Figure S1. Reaction profile during start-up

After 18 min eq of LDA increased to 2.1 eq, conversion increased to $69 \%$ however impurities increased after $28 \mathrm{~min}$ LDA eq returned to $1.4 \mathrm{eq}$ and held at this for $1.5 \mathrm{hr}$, out flow collected for $1.5 \mathrm{hr}$ to give $820 \mathrm{~g}$ of solution. 
HPLC of bulk $67.9 \% 1$

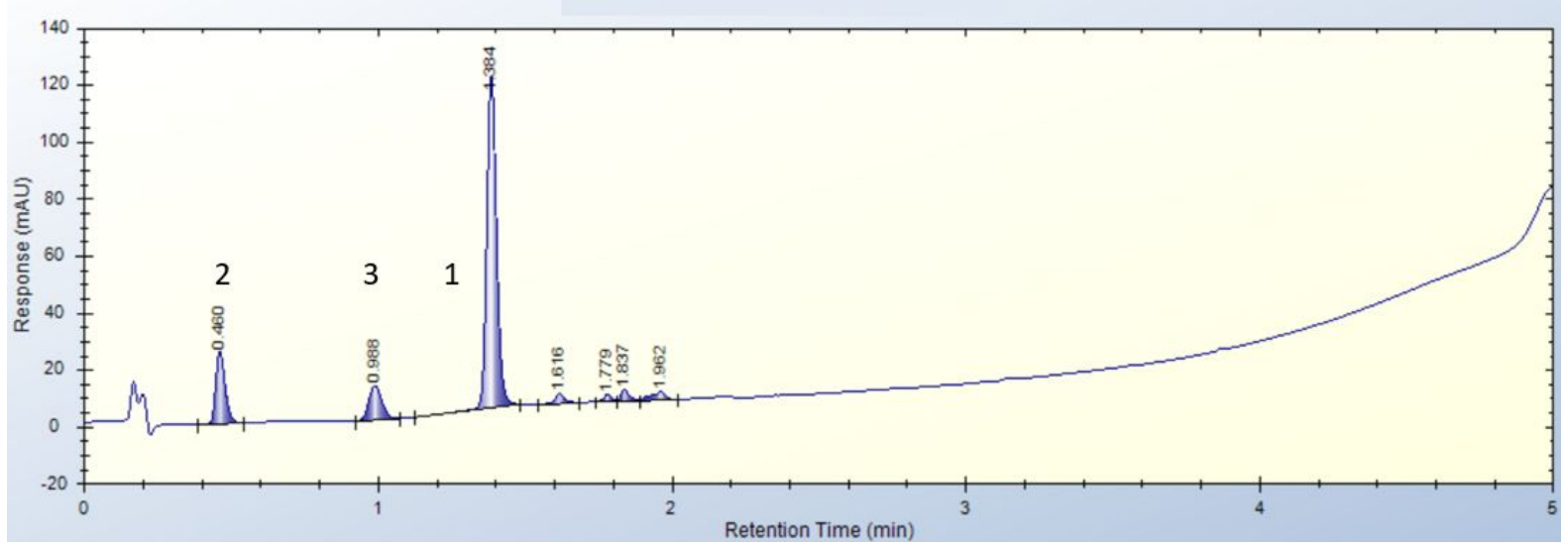

\begin{tabular}{ccc}
\hline Time (min) & \% & Compound \\
\hline 0.46 & 14.24 & 2 \\
0.99 & 9.58 & 3 \\
1.38 & 67.94 & 1 \\
1.62 & 2.15 & Unknown \\
1.78 & 1.23 & Unknown \\
1.84 & 2.08 & Unknown \\
1.96 & 2.75 & Unknown \\
\hline
\end{tabular}


Bulk held at room temperature for 5 days,

HPLC of bulk after 2 days

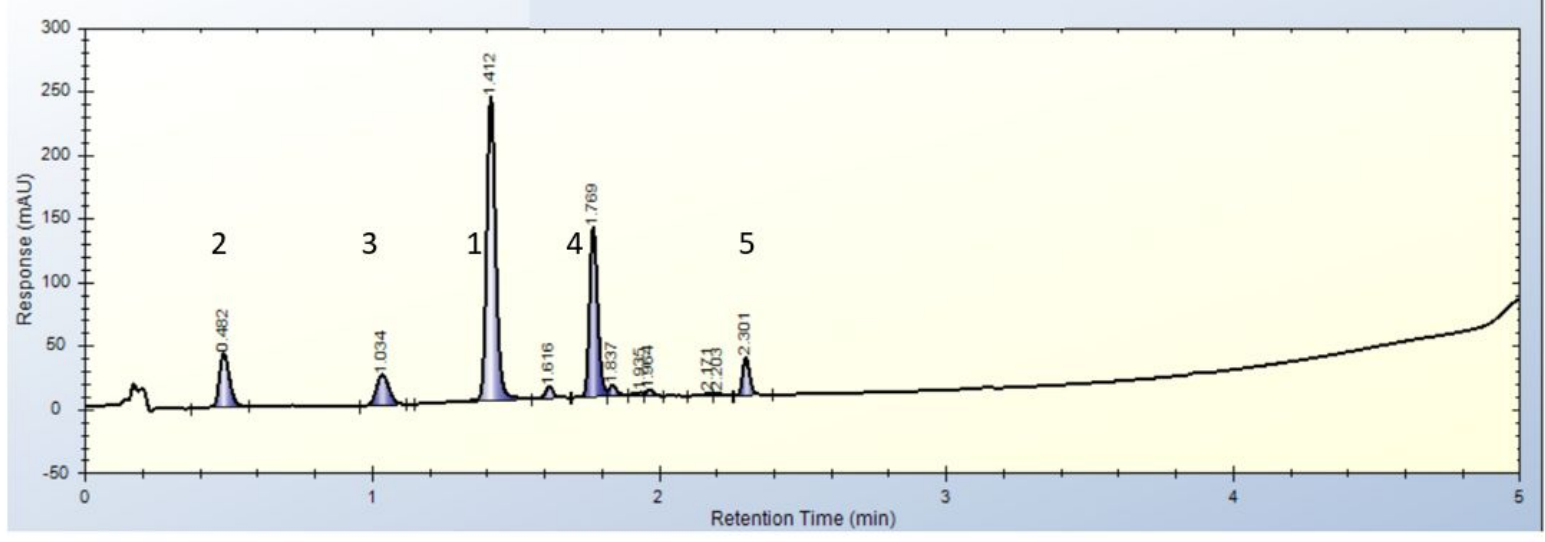

\begin{tabular}{ccc}
\hline Time (min) & \% & Compound \\
\hline 0.48 & 9.62 & 2 \\
1.03 & 6.74 & 3 \\
1.42 & 49.10 & 1 \\
1.62 & 1.93 & Unknown \\
1.77 & 24.35 & 4 \\
1.84 & 1.51 & Unknown \\
1.93 & 0.46 & Unknown \\
1.96 & 0.80 & Unknown \\
2.17 & 0.46 & Unknown \\
2.20 & 0.309 & Unknown \\
2.30 & 4.71 & 5 \\
\hline
\end{tabular}


HPLC of bulk after 5 days

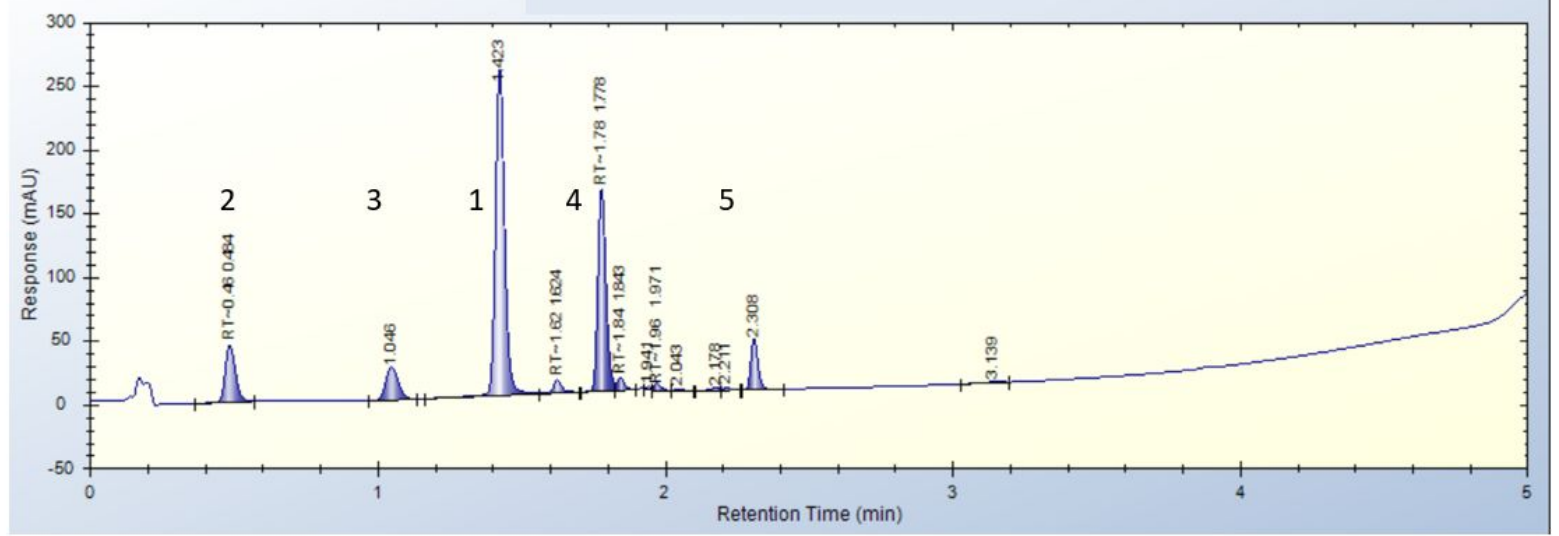

\begin{tabular}{ccc}
\hline Time (min) & \% & Compound \\
\hline 0.48 & 9.28 & 2 \\
1.05 & 6.57 & 3 \\
1.42 & 46.90 & 1 \\
1.62 & 1.85 & Unknown \\
1.78 & 25.90 & 4 \\
1.84 & 1.51 & Unknown \\
1.97 & 0.76 & Unknown \\
2.04 & 0.237 & Unknown \\
2.18 & 0.388 & Unknown \\
2.21 & 0.285 & Unknown \\
2.31 & 5.73 & 5 \\
3.14 & 0.299 & Unknown \\
\hline
\end{tabular}

$\sim 200 \mathrm{~mL}$ of the bulk was taken and washed with $\sim 150 \mathrm{~mL}$ of conc $\mathrm{NH}_{4} \mathrm{Cl}$ and $\sim 150 \mathrm{~mL}$ of sat $\mathrm{NaCl}$. The organic solution was dried over $\mathrm{MgSO}_{4}$, filtered and concentrated in vacuo to obtain $8 \mathrm{~g}$ of crude material.

The crude was purified by chromatographic column (100 g Biotage column, Heptane:EtOAc $0-30 \%)$ to give. the title compound 1-(5-bromopyridin-2-yl)-2-methylpropan-2-ol 1 as a 
yellow oil $4.037 \mathrm{~g}$ and 2-(5-bromo-2-methylpyridin-3-yl)propan-2-ol 3 as yellow waxy solid $751 \mathrm{mg}$.

1-(5-bromopyridin-2-yl)-2-methylpropan-2-ol 1 as a yellow oil $4.037 \mathrm{~g}$

1H NMR (400 MHz, DMSO-d6) $\delta 1.09$ (s, 7H), 2.80 (s, 2H), 3.26-3.37 (m, 1H), 4.55 (s, 1H), 7.20-7.39 (m, 1H), 7.88-7.98 (m, 1H), 8.55-8.65 (m, 1H); HPLC: tR = 1.30 min (TFA)

(100\% purity by UV); .LC/MS, $0.68 \mathrm{~min}\left(\mathrm{ES}^{+}\right) \mathrm{m} / \mathrm{z}$ (relative intensity) $230.01 / 231.98([\mathrm{M}+$ $\left.\mathrm{H}]^{+}, 85\right)$.

2-(5-bromo-2-methylpyridin-3-yl)propan-2-ol 3 a yellow waxy solid $751 \mathrm{mg}$ 1H NMR (400 MHz, DMSO-d6) $\delta 1.58(\mathrm{~s}, 6 \mathrm{H}), 2.44$ (s, 3H), 3.32 (s, 2H), $5.46(\mathrm{~s}, 1 \mathrm{H}), 7.65$ $(\mathrm{s}, 1 \mathrm{H}), 8.48(\mathrm{~s}, 1 \mathrm{H}) ; \mathrm{HPLC}: \mathrm{tR}=1.30 \mathrm{~min}(\mathrm{TFA})(100 \%$ purity by UV); .LC/MS, $0.54 \mathrm{~min}$ $(\mathrm{ES}+) \mathrm{m} / \mathrm{z}$ (relative intensity) 230.02/232.01 ([M + H]+.,90).

4-hydroxy-4-methylpentan-2-one 4 not isolated.

5-bromo-2-(2-methylprop-1-en-1-yl)pyridine 5 not isolated, 5 is volatile at $40{ }^{\circ} \mathrm{C}$ believed to have been removed during the concentration step.

In addition to confirm the non-volatility of 1-(5-bromopyridin-2-yl)-2-methylpropan-2-ol 1 , it was subjected to $10 \mathrm{mbar}$ at $40^{\circ} \mathrm{C}$ on evaporator for $2 \mathrm{hr}$, no change in weight. However 1 observed to co-distil with solvents. 
Synthesis of 1-(5-bromopyridin-2-yl)-2-methylpropan-2-ol monohydrochloride 1
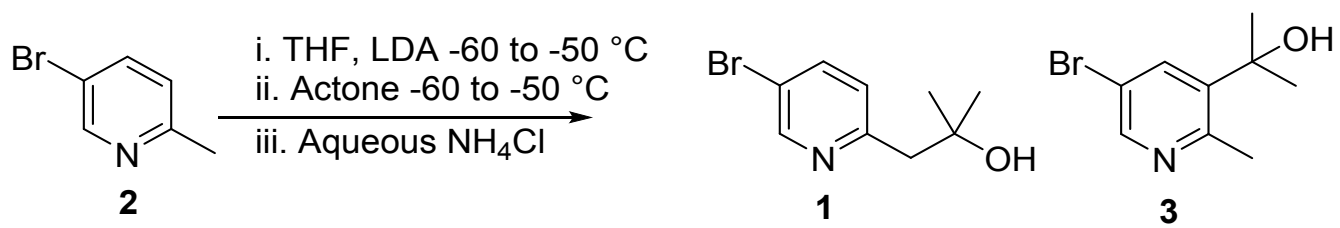

Dry acetone: Calcium sulfate $(80 \mathrm{~g}, 588 \mathrm{mmol})$ was added to acetone $(1800 \mathrm{~mL})$, mixture was allowed to stand at room temperature overnight.

5-bromo-2-methylpyridine 2 ( $50 \mathrm{~g}, 291 \mathrm{mmol})$ was dissolved in dry Tetrahydrofuran (THF, $1000 \mathrm{ml})$

Bottle to bottle variance of the same batch of 1M LDA in THF:Hexanes (1:7) had been observed, before any flow runs the bottle of LDA is use tested in small scale batch reactions. $1 \mathrm{~mL}$ 5-bromo-2-methylpyridine 2 in THF cooled to -70C 1.1 to 2.5 eq LDA added stirred for $2 \mathrm{~min}$ then quenched with $1 \mathrm{~mL}$ dry acetone added HPLC taken then quenched with 100 ul sat $\mathrm{NH}_{4} \mathrm{Cl}$ soln. See Figure $\mathrm{S} 2$ for results 


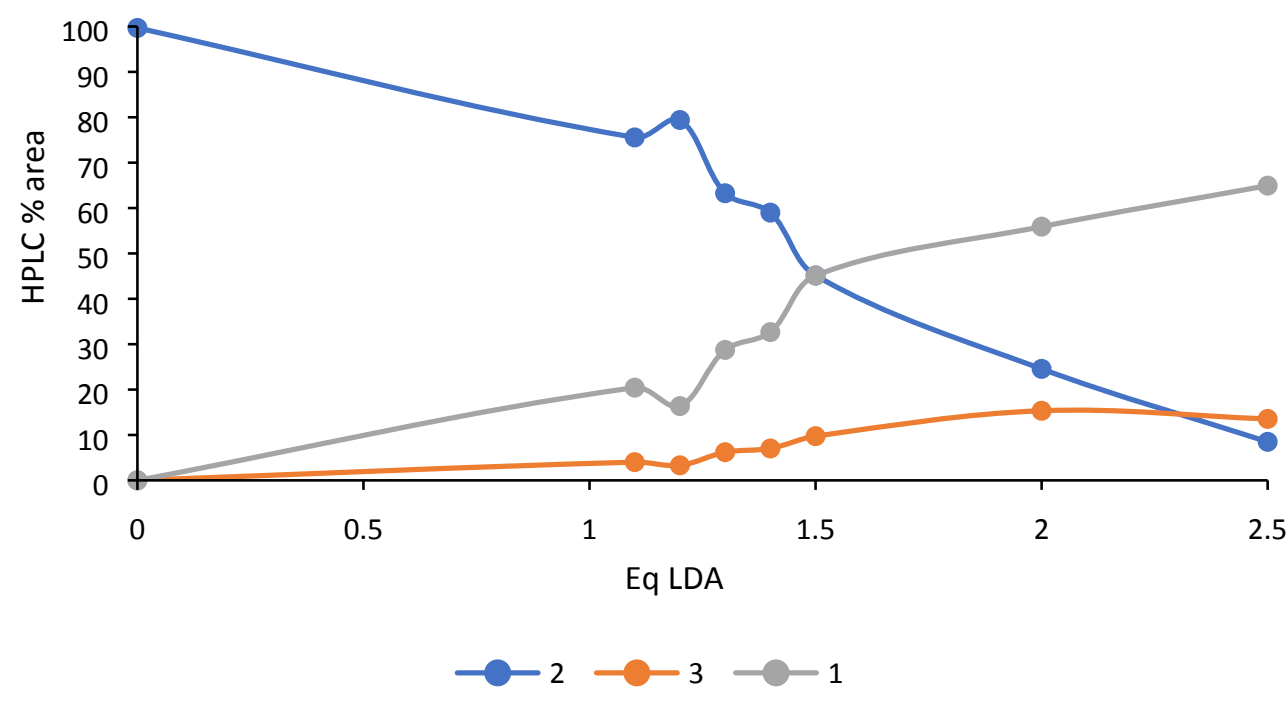

Figure S2. Eq LDA vs conversion to 1

System cooled to $-60{ }^{\circ} \mathrm{C}$, flowed onto $\mathrm{NH}_{4} \mathrm{Cl}$ quench

Start at 1.8 eq LDA, for $36 \mathrm{~min}$

1M LDA in THF:Heaxanes (1:7) $3.15 \mathrm{~g} / \mathrm{min}$

Feedline $7.85 \mathrm{~g} / \mathrm{min}$ 5-bromo-2-methylpyridine $2 \mathrm{THF}$ solution

Acetone $1.61 \mathrm{ml} / \mathrm{min}$

2.1 eq for $30 \mathrm{~min}$

1M LDA in THF:Heaxanes (1:7) $3.51 \mathrm{~g} / \mathrm{min}$

Feedline $7.49 \mathrm{~g} / \mathrm{min}$ 5-bromo-2-methylpyridine $2 \mathrm{THF}$ solution

Acetone $1.53 \mathrm{ml} / \mathrm{min}$

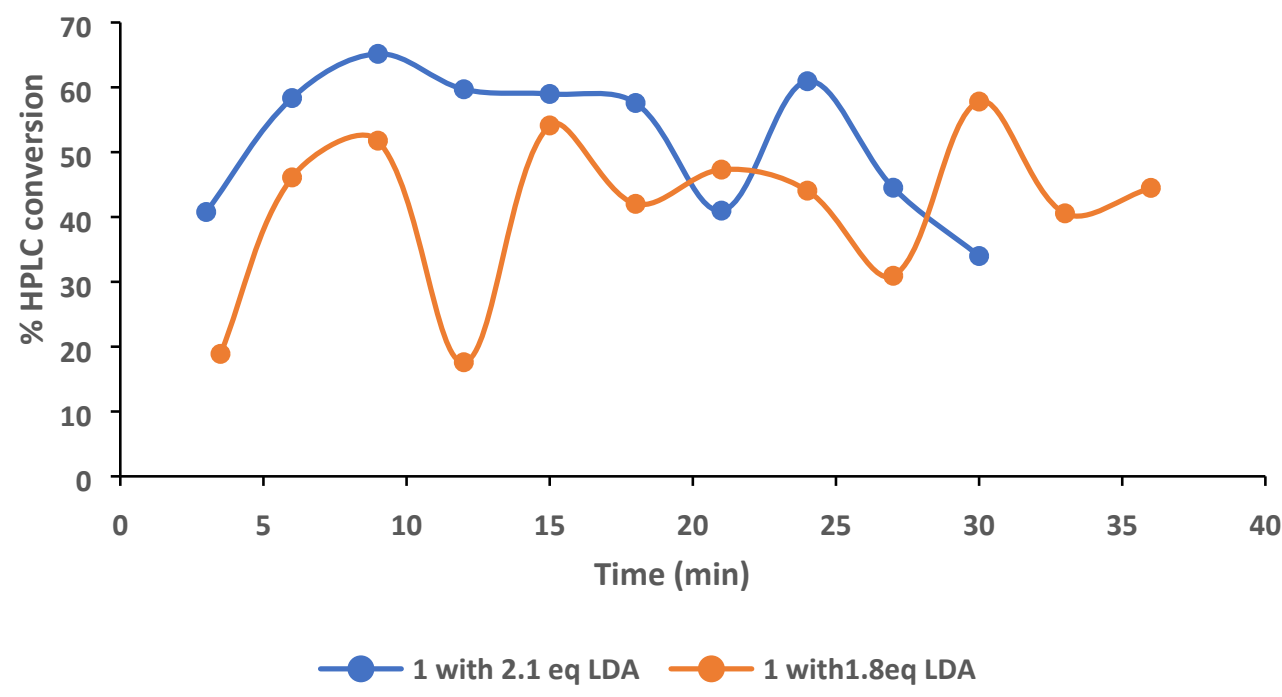

Figure S3. Conversion monitored over $30 \mathrm{~min} 1.8$ eq LDA vs 2.1 eq LDA 
$\sim 900 \mathrm{ml}$ collected between the both runs, $643 \mathrm{ml}$ 5-bromo-2-methylpyridine 2 THF solution (183.62 mmol) processed max yield of $42.25 \mathrm{~g}$

Organic and aqueous separated.

Wgt of organic $771.02 \mathrm{~g}, \mathrm{~d}=0.8362,922.05 \mathrm{~mL}$, HPLC $52.07 \% \mathbf{1}, 32.72 \% \mathbf{2}, 7.45 \% \mathbf{3}$

Concentrated in vacuo $\left(130 \mathrm{mbar} 40^{\circ} \mathrm{C}\right)$ to give a brown oil $62.09 \mathrm{~g}$, loaded onto a $50 \mathrm{~g}$ Biotage column, followed by a $340 \mathrm{~g}$ Biotage column (Heptane:EtOAc 0-30\%).

Relevante fractions concentrated in vacuo $\left(108\right.$ mbar $\left.40^{\circ} \mathrm{C}\right)$.

Recovered 5-bromo-2-methylpyridine $27.75 \mathrm{~g}$

${ }^{1} \mathrm{H}$ NMR (400 MHz, DMSO-d 6 ) $\delta 2.44(\mathrm{~s}, 3 \mathrm{H}), 7.26$ (d, $\left.J=8.37 \mathrm{~Hz}, 1 \mathrm{H}\right), 7.91$ (dd, $J=8.37$, $2.46 \mathrm{~Hz}, 1 \mathrm{H}), 8.55(\mathrm{~d}, J=2.46 \mathrm{~Hz}, 1 \mathrm{H})$

Adjusting processed material for recovered 2 183.62-45 $=138.62 \mathrm{mmol}$ max adjusted yield of $131.897 \mathrm{~g}$

Relevant fractions concentrated in vacuo $\left(88 \mathrm{mbar} 40^{\circ} \mathrm{C}\right)$.

1-(5-bromopyridin-2-yl)-2-methylpropan-2-ol 1 to give a yellow oil, $20.48 \mathrm{~g}$ transferred a smaller flask with $\mathrm{MeOH}$, and concentrated to give $15.34 \mathrm{~g}$

NMR (DMSO-d6) trace MeOH, 1: 4-hydroxy-4-methyl-2-pentanone (bpt $\left.22{ }^{\circ} \mathrm{C}\right)$ 2.6:1

Note: 4-Hydroxy-4-methyl-2-pentanone, comes from the aldol of acetone with its self in the presence of LDA, further evaporation indicates that 1 co-distils with solvent.

Impure 1 dissolved in $10 \mathrm{ml}$ EtOAc to this mixture was added $40 \mathrm{~mL} 2 \mathrm{M} \mathrm{HCl}$ in ether an off white solid drops out of solution stirred at room temperature for $30 \mathrm{~min}$, filtered, cake washed on funnel with $15 \mathrm{~mL}$ EtOAc, dried on high vac at $45{ }^{\circ} \mathrm{C}$ overnight. To give the title compound 1-(5-bromopyridin-2-yl)-2-methylpropan-2-ol 1 as the monohydrochloride salt 13.9770 g. 38\% 1H NMR (400 MHz, DMSO-d6) $\delta 1.11(\mathrm{~s}, 6 \mathrm{H}), 2.88(\mathrm{~s}, 2 \mathrm{H}), 7.38-7.52(\mathrm{~m}$, 1H), $7.77($ br s, $1 \mathrm{H}), 8.05-8.23(\mathrm{~m}, 1 \mathrm{H}), 8.65-8.84(\mathrm{~m}, 1 \mathrm{H})$; HPLC: $\mathrm{tR}=1.31 \mathrm{~min}(\mathrm{TFA})$ (99.09\% purity by UV); 
Synthesis of 1-(5-bromopyridin-2-yl)-2-methylpropan-2-ol 1 final processing run

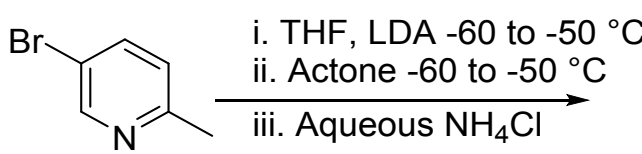

2<smiles>CC(C)(O)Cc1ccc(Br)cn1</smiles>

1<smiles>Cc1ncc(Br)cc1C(C)(C)O</smiles>

3

Bottle to bottle variance of the same batch of 1M LDA in THF:Hexanes (1:7) had been observed, before any flow runs the $500 \mathrm{~mL}$ bottles of LDA were use tested in small scale batch reactions.

$1 \mathrm{~mL}$ 5-bromo-2-methylpyridine $2(50 \mathrm{mg})$ in THF cooled to $-70{ }^{\circ} \mathrm{C} 1.1$ to 2.1 eq LDA added stirred for 2 min then quenched with $1 \mathrm{~mL}$ dry acetone added HPLC taken then quenched with 100 ul sat $\mathrm{NH}_{4} \mathrm{Cl}$ soln. See Figure $\mathbf{S 4}$ for results

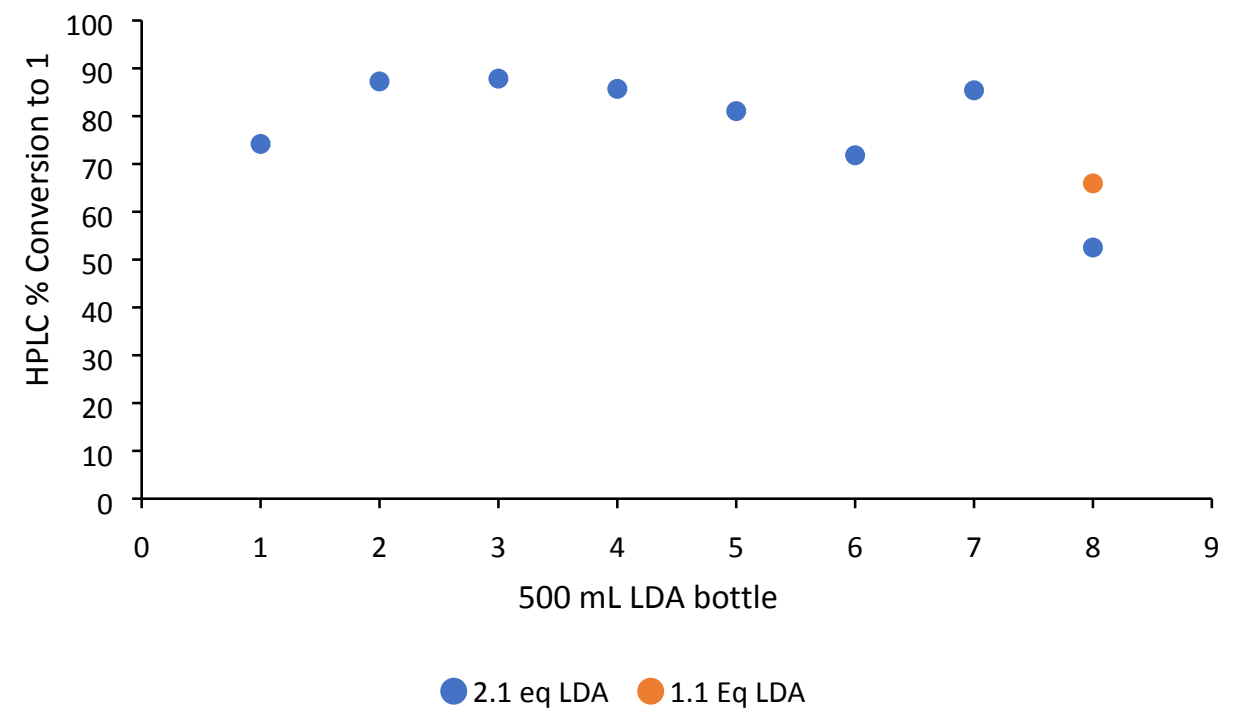

Figure S4. Results of use test of $500 \mathrm{~mL}$ bottles of LDA in THF:hexanes from the same batch.

Details of processing runs in main manuscript. 


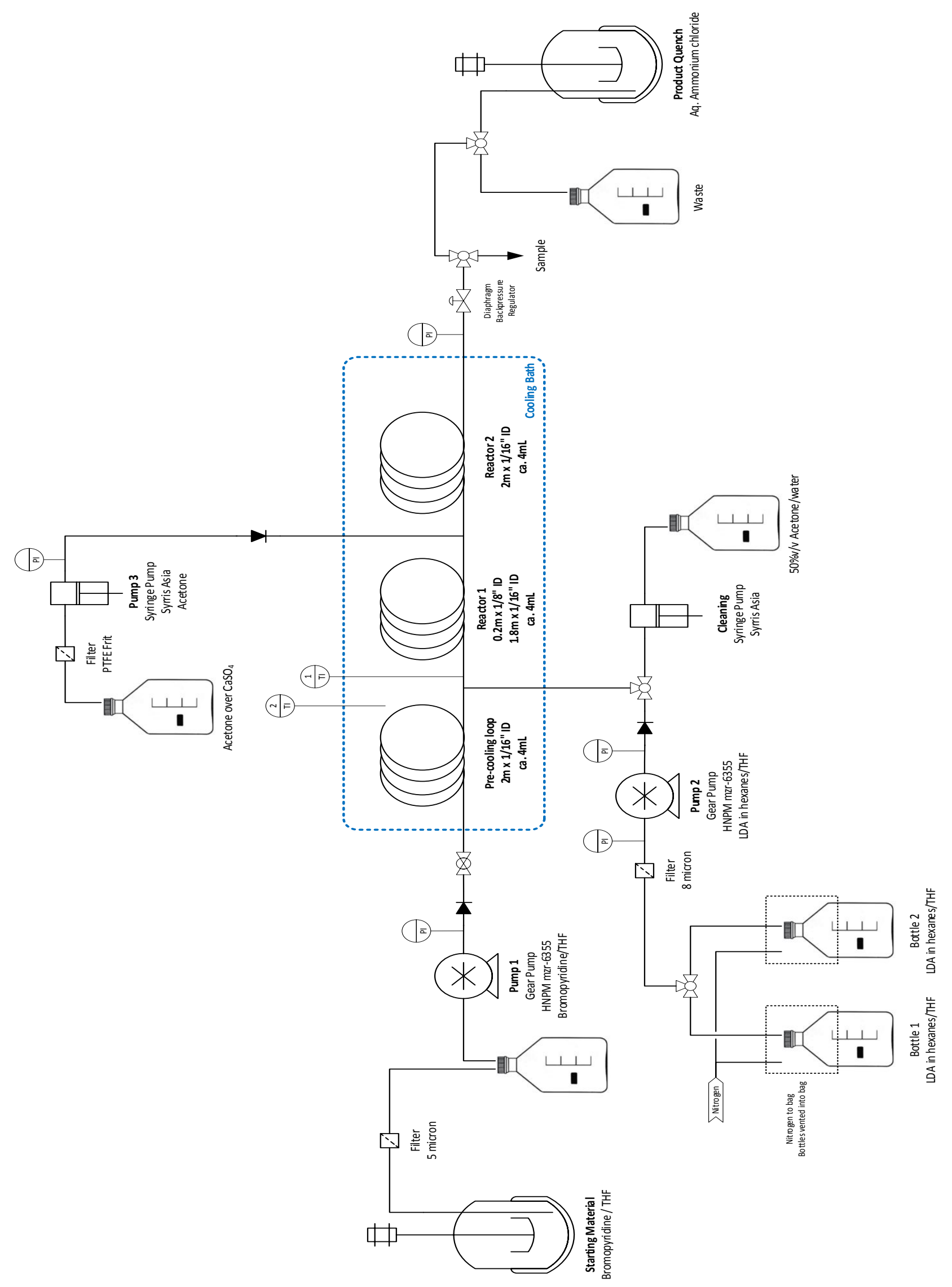

Figure S5. Final equipment diagram for flow synthesis of $\mathbf{1}$. 


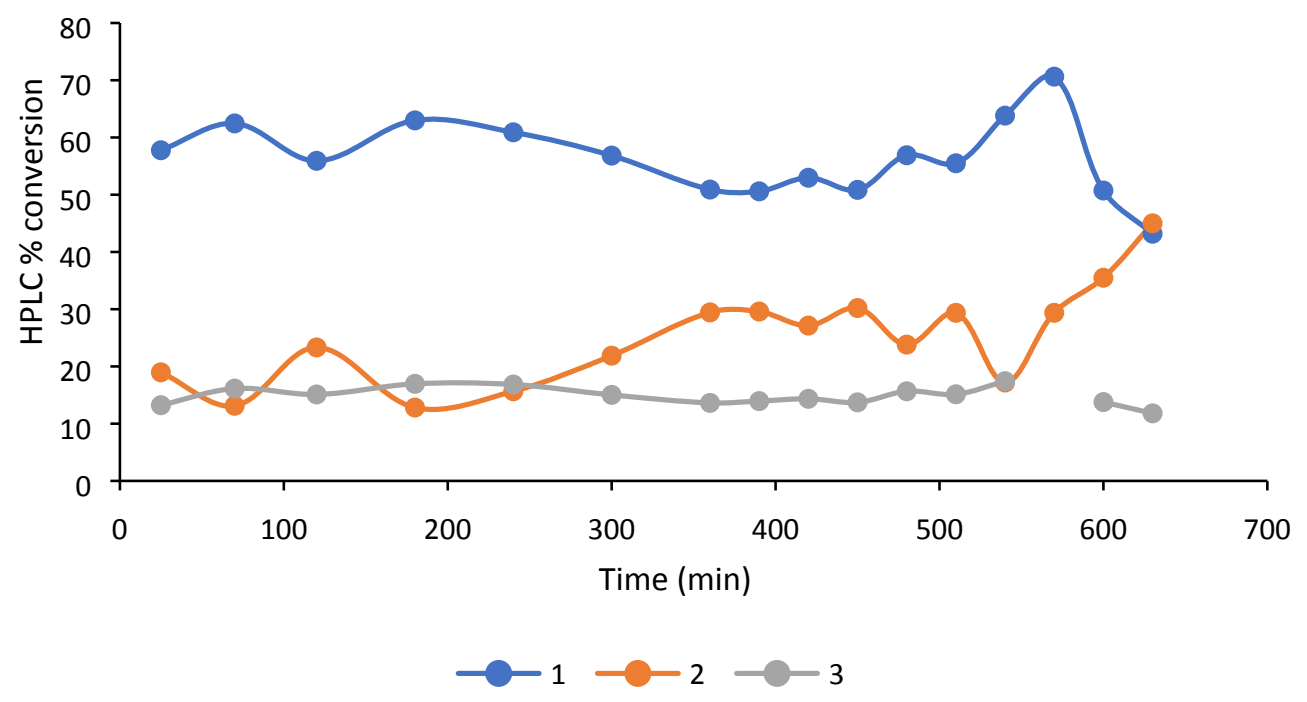

Figure S6. Reaction profile over $10 \mathrm{hr}$ processing $300 \mathrm{~g} 2$ figure 19 in manuscript.

HPLC of bulk from processing $300 \mathrm{~g} 2$

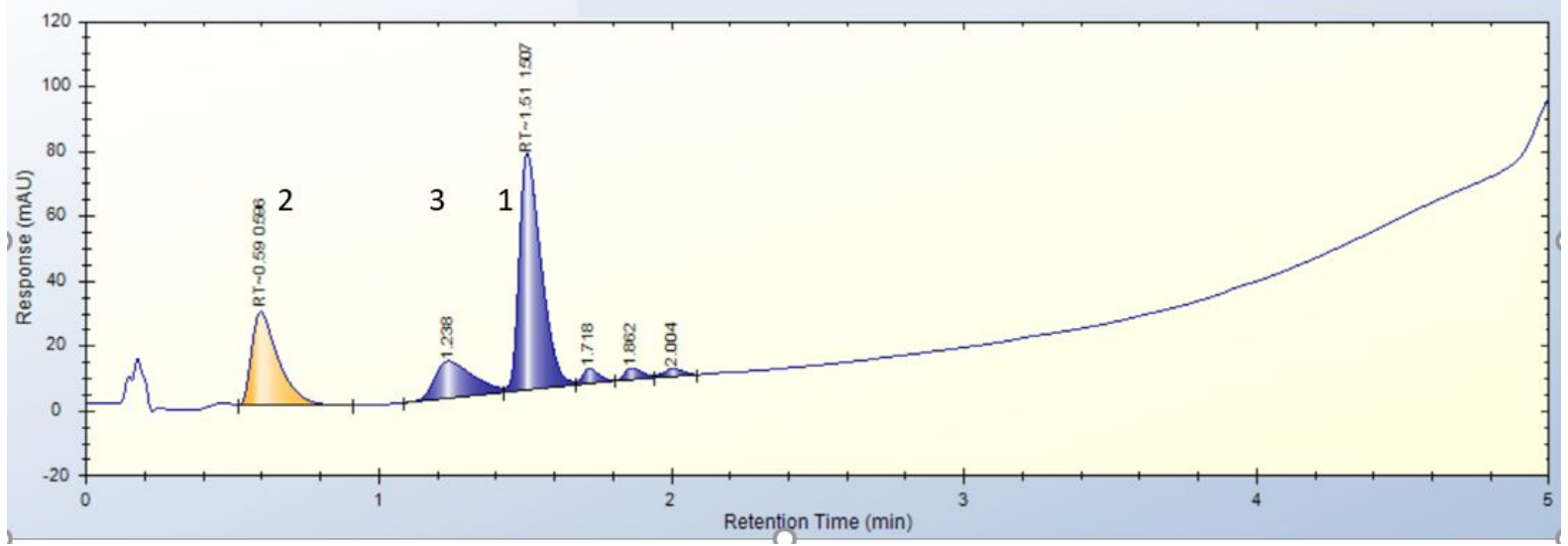

Note: Peaks are broad due defective guard column

\begin{tabular}{ccc}
\hline Time (min) & \% & Compound \\
\hline 0.59 & 25.9 & 2 \\
1.24 & 14.5 & 3 \\
1.51 & 53.4 & 1 \\
1.72 & 2.5 & Unknown \\
1.86 & 2.08 & Unknown \\
2.00 & 1.64 & Unknown \\
\hline
\end{tabular}


Results

Solution $\mathrm{d}=0.8275$

Vessel weight $\quad 7.98 \mathrm{~kg}$

Vessel tare $\quad 2.66 \mathrm{~kg}$

Solution weight $5.32 \mathrm{~kg}$

Solution volume $6.43 \mathrm{~L}$

Solution volume $6429.61 \mathrm{~mL}$

Solution assay of $1119795.9331 \mathrm{mg}$

Solution assay of $\mathbf{1} 119.80 \mathrm{~g} 30 \%$

Concentrated in vacuo $\left(130 \mathrm{mbar} 40^{\circ} \mathrm{C}\right)$ to give a brown oil $1105 \mathrm{~g}, 498 \mathrm{~g}$ loaded onto a 3 kg Biotage column (Heptane:EtOAc 0-40\%, two $498 \mathrm{~g}$ batches purified). Note Part of batch (109 $\mathrm{g}, \sim 15 \mathrm{~g}$ of $\mathbf{1})$ lost during an attempt at distilling the crude product.

Relevante fractions concentrated in vacuo $\left(100 \mathrm{mbar} 40^{\circ} \mathrm{C}\right)$.

To remaining solution $250 \mathrm{ml} 4 \mathrm{M} \mathrm{HCl}$ in dioxane added, an off white solid drops out of solution stirred at room temperature for $30 \mathrm{~min}$, filtered, cake washed on funnel with $150 \mathrm{~mL}$ EtOAc, dried on high vac at $45^{\circ} \mathrm{C}$ overnight.

To give the title compound 1-(5-bromopyridin-2-yl)-2-methylpropan-2-ol 1 in two batches as the monohydrochloride salt.

Batch 166.4 g $14.3 \%$

Batch 264.7 g 13.9\%

1H NMR (400 MHz, DMSO-d6) $\delta 1.11(\mathrm{~s}, 6 \mathrm{H}), 2.88$ (s, 2H), 7.38-7.52 (m, 1H), 7.77 ( br s, $1 \mathrm{H}), 8.05-8.23(\mathrm{~m}, 1 \mathrm{H}), 8.65-8.84(\mathrm{~m}, 1 \mathrm{H})$ 


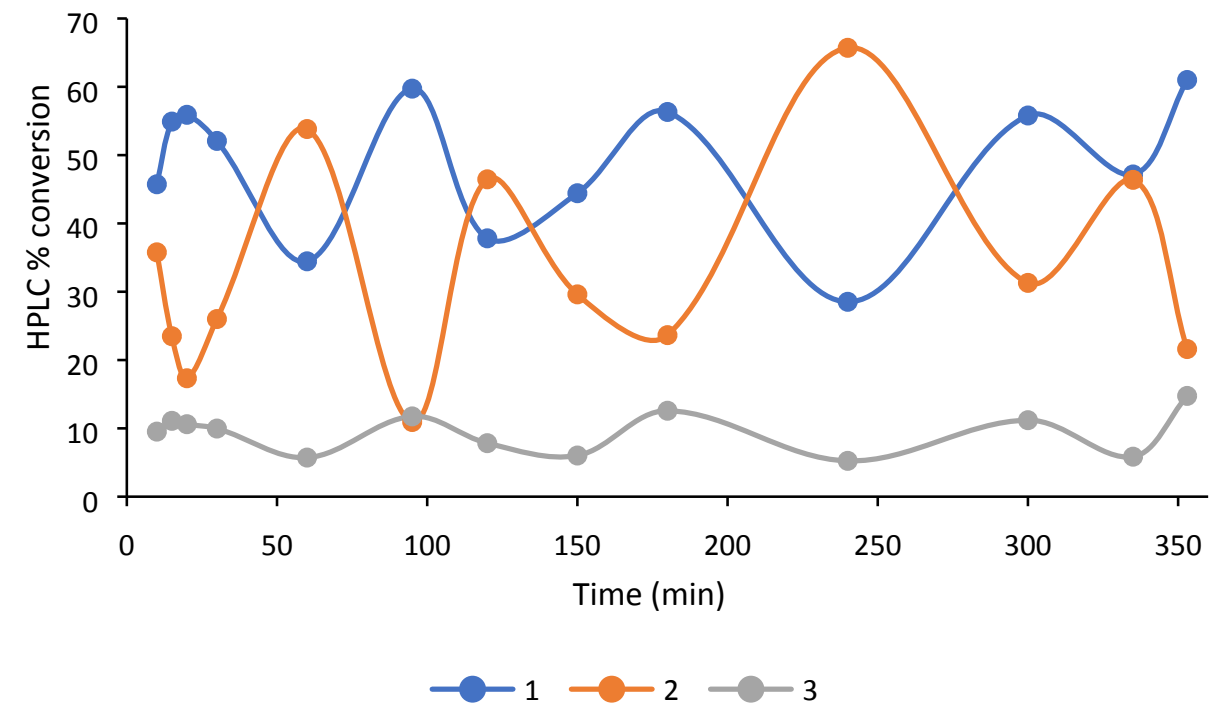

Figure S7. Reaction profile over $6 \mathrm{hr}$ processing $200 \mathrm{~g} \mathrm{2}$, shape of graph is due to LDA filter blinding over time, figure 21 in manuscript..

HPLC of bulk from processing $200 \mathrm{~g} 2$

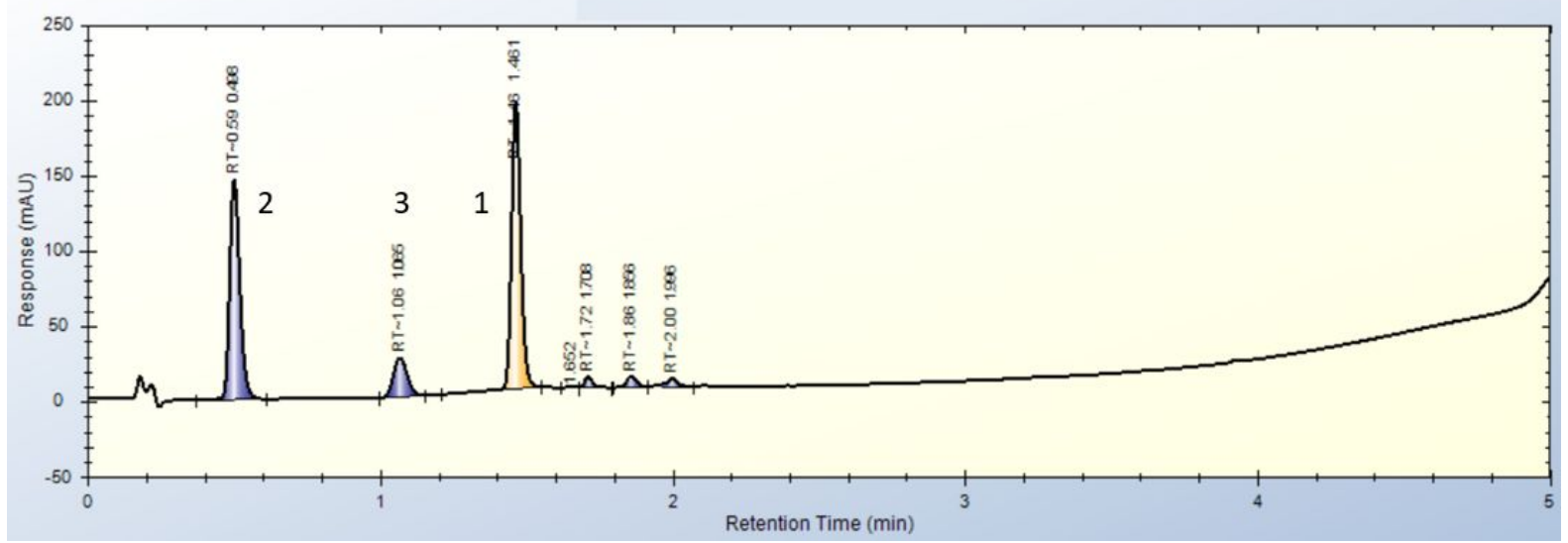

\begin{tabular}{ccc}
\hline Time (min) & \% & Compound \\
\hline 0.59 & 39.1 & 2 \\
1.24 & 9.4 & 3 \\
1.51 & 45.8 & 1 \\
1.72 & 1.7 & Unknown \\
1.86 & 2.0 & Unknown \\
2.00 & 1.8 & Unknown \\
\hline
\end{tabular}

Vessel weight $6.69 \mathrm{~kg}$ 
Vessel tare $\quad 2.66 \mathrm{~kg}$

Solution weight $4.03 \mathrm{~kg}$

Solution volume $4.87 \mathrm{~L}$

Solution volume $4868.88 \mathrm{~mL}$

Solution assay of $\mathbf{1} 89733.31 \mathrm{mg}$

Solution assay of $189.73 \mathrm{~g} \mathrm{33.5 \%}$

Concentrated in vacuo $\left(130 \mathrm{mbar} 40^{\circ} \mathrm{C}\right)$ to give a brown oil $317 \mathrm{~g}$, loaded onto a $1.5 \mathrm{~kg}$ Biotage column (Heptane:EtOAc 0-30\%).

Relevante fractions concentrated in vacuo $\left(100 \mathrm{mbar} 40^{\circ} \mathrm{C}\right)$.

To remaining solution $100 \mathrm{ml} 4 \mathrm{M} \mathrm{HCl}$ in dioxane added, an off white solid drops out of solution stirred at room temperature for $30 \mathrm{~min}$, filtered, cake washed on funnel with $100 \mathrm{~mL}$ EtOAc, dried on high vac at $45^{\circ} \mathrm{C}$ overnight.

To give the title compound 1-(5-bromopyridin-2-yl)-2-methylpropan-2-ol 1 in two batches as the monohydrochloride salt, $95.42 \mathrm{~g}, 30.8 \%$

1H NMR (400 MHz, DMSO-d6) $\delta 1.11$ (s, 6H), 2.88 (s, 2H), 7.38-7.52 (m, 1H), 7.77 ( br s, $1 \mathrm{H}), 8.05-8.23(\mathrm{~m}, 1 \mathrm{H}), 8.65-8.84(\mathrm{~m}, 1 \mathrm{H})$

Photos of 2M LDA in THF/heptane/ethylbenzene after cooling to $<-60^{\circ} \mathrm{C}$

Figure S8 supports Table 1 in main manuscript.
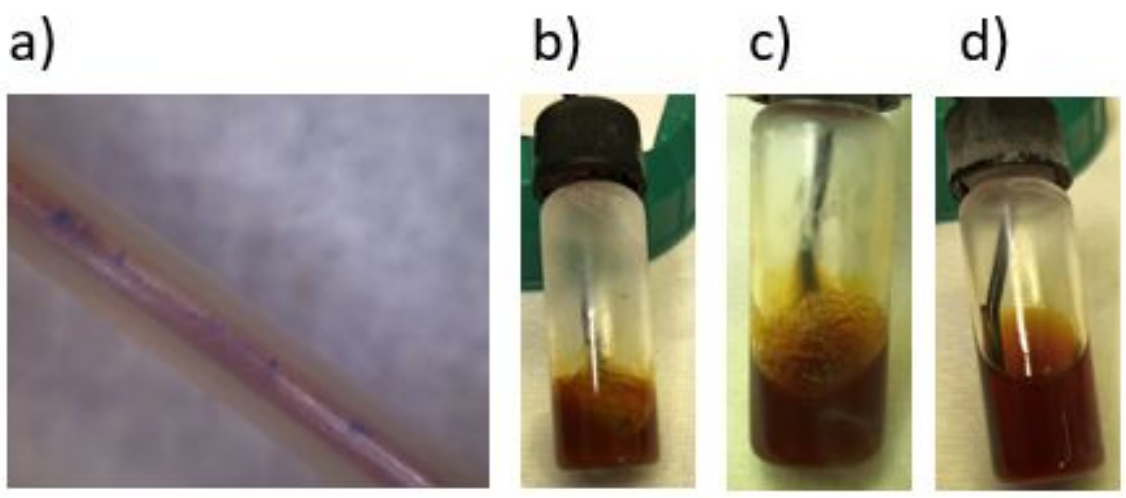

Figure S8. a) $2 \mathrm{M} \mathrm{LDA}$ in THF/heptane/ethylbenzene in $1 / 32$ th ID tubing held at $-70{ }^{\circ} \mathrm{C}$ solids in tubing, b) $2 \mathrm{M} \mathrm{LDA}$ in THF/heptane/ethylbenzene in $4 \mathrm{ml}$ Wheaton vial at $-66^{\circ} \mathrm{C}$ frozen solid, c) $1.538 \mathrm{M} \mathrm{LDA}$ in THF/heptane/ethylbenzene in $4 \mathrm{ml}$ Wheaton vial at $-67^{\circ} \mathrm{C}$, semi-solid, d) $2 \mathrm{M} \mathrm{LDA}$ in THF/heptane/ethylbenzene in $4 \mathrm{ml}$ Wheaton vial at $-68.1^{\circ} \mathrm{C}$ solution. 


\section{NMR Spectra}

${ }^{1} \mathrm{H}$ NMR DMSO 1-(5-bromopyridin-2-yl)-2-methylpropan-2-ol 1

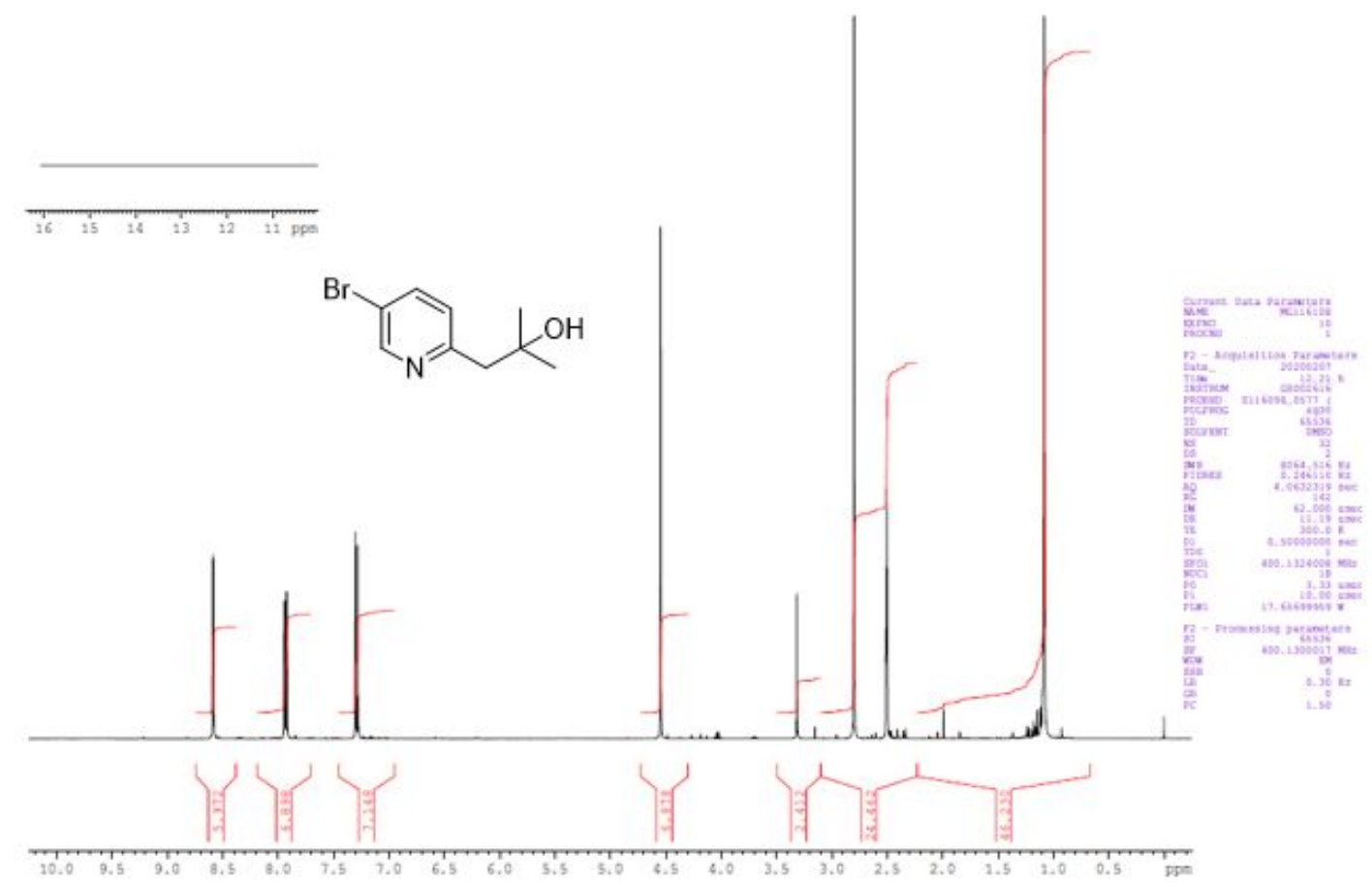

${ }^{1} \mathrm{H}$ NMR DMSO 1-(5-bromopyridin-2-yl)-2-methylpropan-2-ol monohydrochloride 1

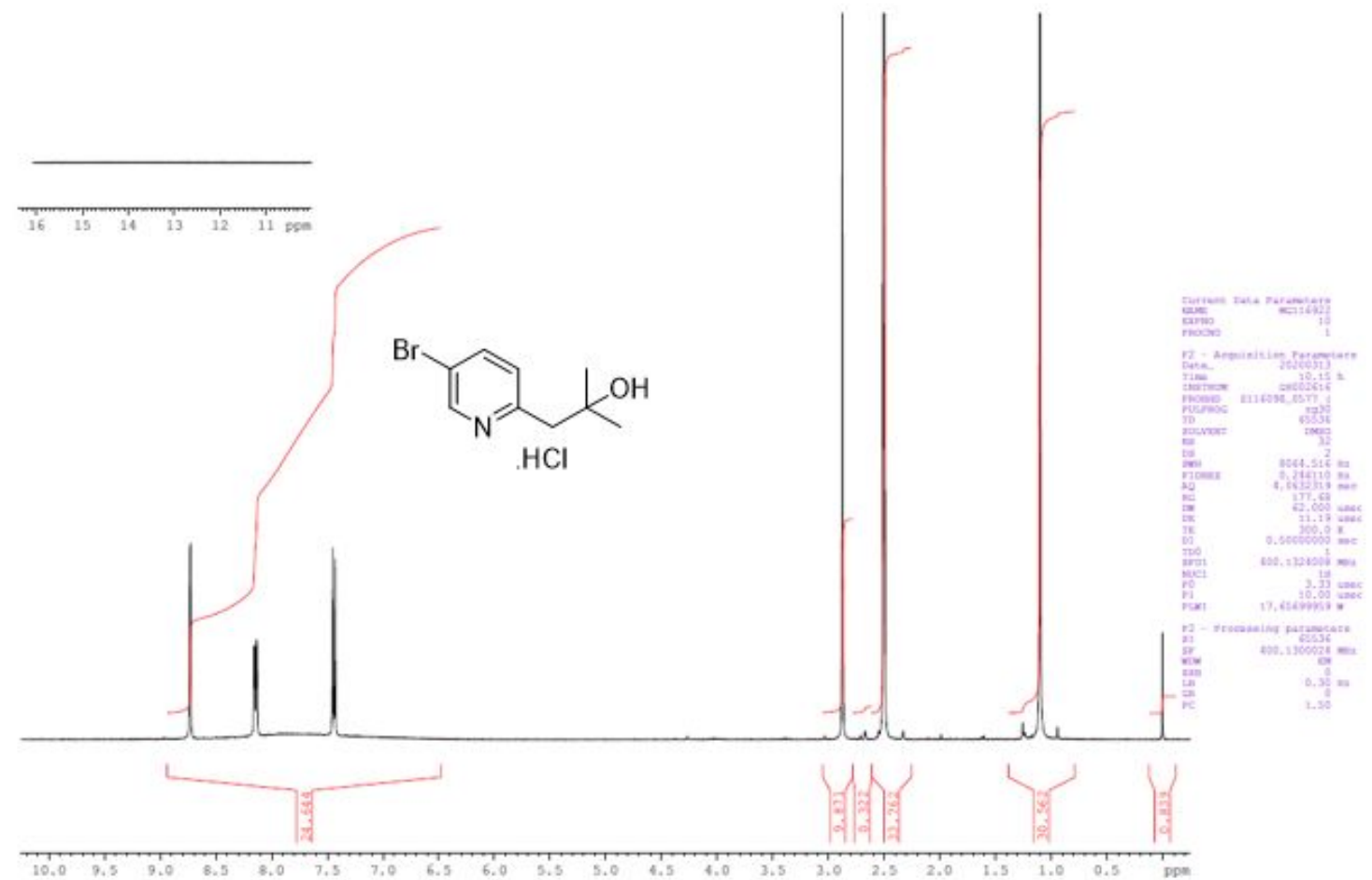


${ }^{1} \mathrm{H}$ NMR DMSO 2-(5-bromo-2-methylpyridin-3-yl)propan-2-ol 3

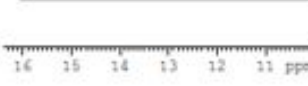<smiles>Cc1ncc(Br)cc1C(C)(C)O</smiles>
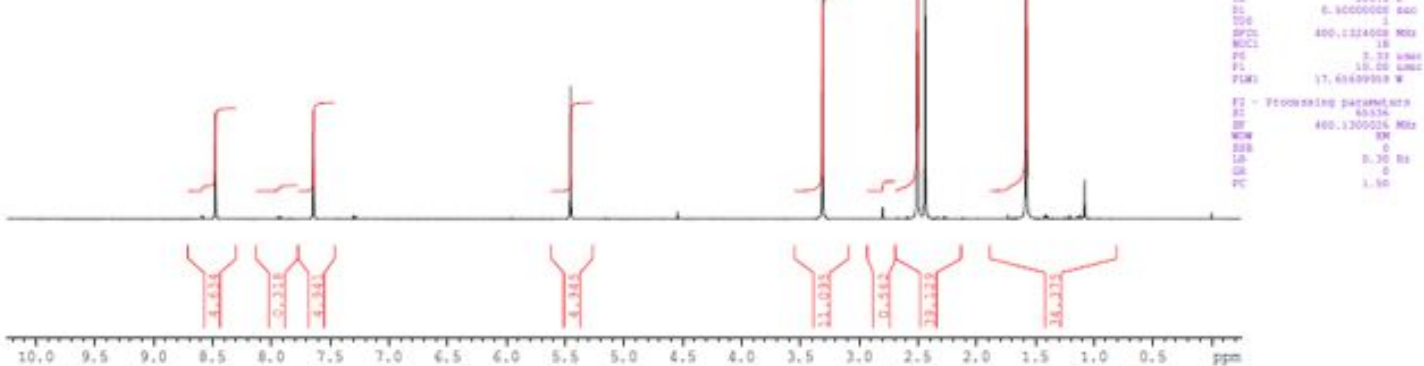

${ }^{1} \mathrm{H}$ NMR DMSO 5-bromo-2-(2-methylprop-1-en-1-yl)pyridine 5

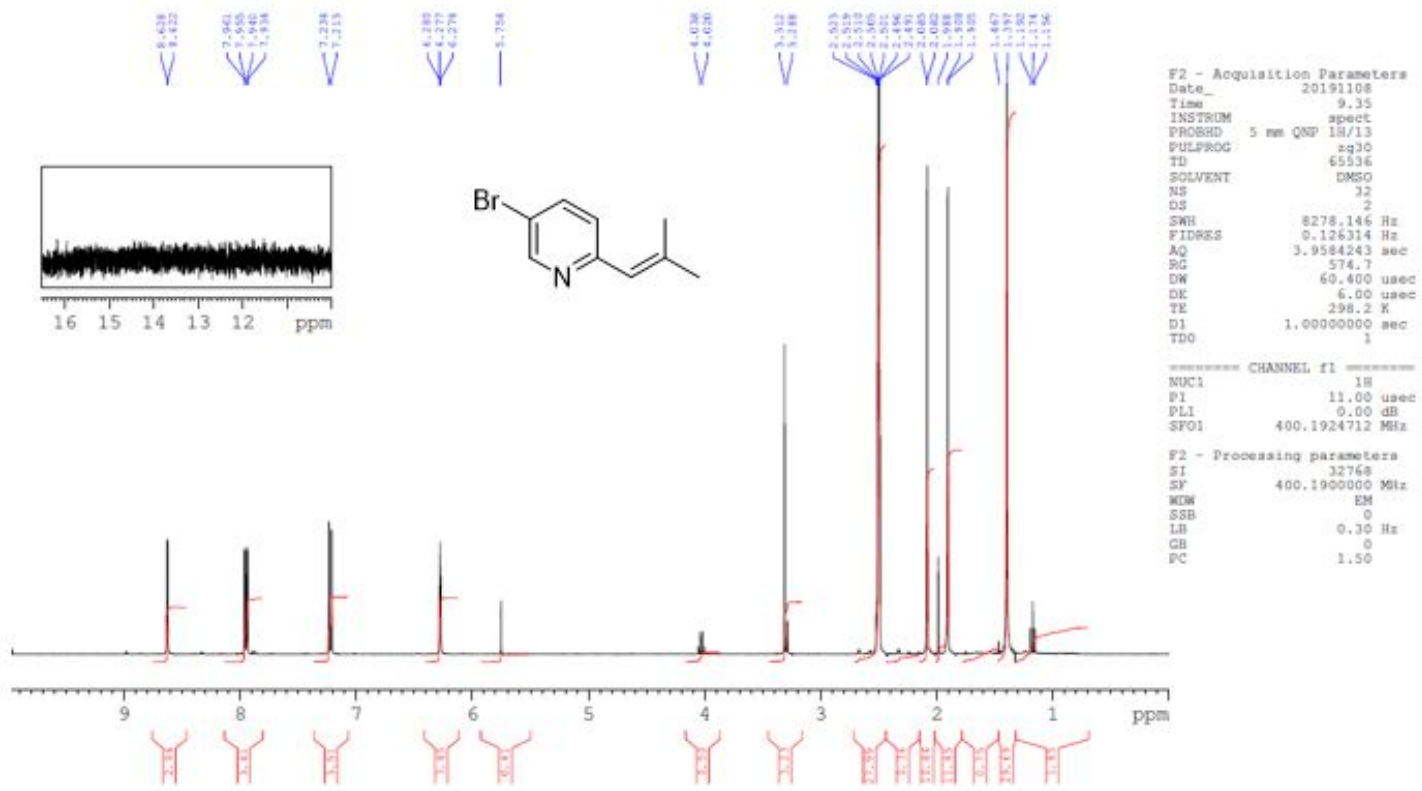

Note: NMR contains cyclohexane (1.40 ppm), trace DCM and trace ethyl acetate. 
${ }^{1} \mathrm{H}$ NMR DMSO 5-bromo-2-methylpyridine 2
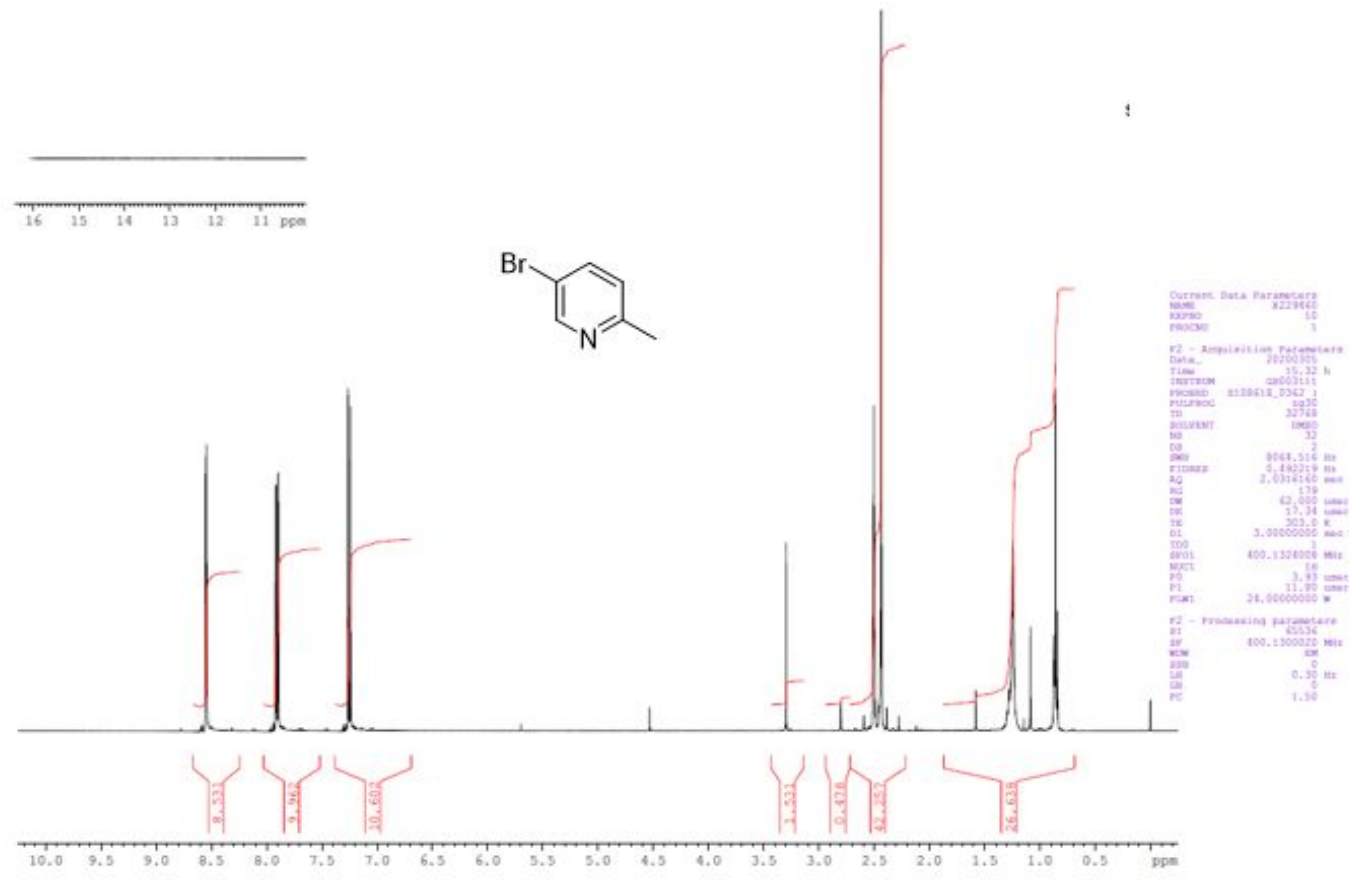

Note: NMR contains heptane. 